\title{
ON THE ADVERTISEMENT OF ALCOHOLIC BEVERAGES AND THE OMISSION OF BRAZILIAN DOCTORS
}

\author{
Geilson Lima Santana, Bruno Mendonça Coelho, Yuan Pang Wang
}

In November 2005, Brazilian National Health Surveillance Agency (ANVISA) published the $83^{\text {rd }}$ Public Consultation, which wells upon the regulation of alcohol advertisement. Nevertheless, in spite of the relevance of this question and its impact on public health, the debate within the medical community has been expressionless.

According to the World Health Organization (WHO), the consumption of alcohol in Brazil increased $74.5 \%$ from 1970 to1990. Presently, the beer market puts in circulation an annual amount of US\$ 12 billion and Brazil stands as fifth global market ${ }^{1}$. This is a highly competitive niche and companies fight for the differentiation of their products sustained by aggressive and successful strategies: the relationship between investment on propaganda and alcohol consumption is well known by the industry, advertisers and mass media. Each additional dollar invested in the publicity of ethanol results in a $3 \%$ increase in its consumption by the youth ${ }^{2}$. In 2001, US\$ 106 million were invested in the advertising of alcoholic beverages in Brazil and, since then, there was a $2 \%$ increase in the prevalence of alcoholism among those aged 12 to 17 years. A $7 \%$ prevalence of alcohol dependence is estimated for this population ${ }^{3}$.

Choosing youth as target for marketing is a strategic decision: alcohol advertising influences the initiation and continuation of ethanol ingestion by the underage, the amount and frequency of its ingestion and predicts further

Instituto de Psiquiatria - Núcleo de Epidemiologia Psiquiátrica - Hospital das Clínicas da Faculdade de Medicina da Universidade de São Paulo, SPBrazil

Email: geilson.santana@hotmail.com dependence in adulthood ${ }^{2}$. The effects of marketing are cumulative and, in this manner, the industry assures the perspective of a sustained growth.

However, this population is the most vulnerable to harmful consequences of alcohol. As demonstrated by Pechansky et al., this substance is more strongly associated with mortality among youths than all other drugs put together; being under the effects of alcohol augments the chance of sexual violence and unsafe sexual behavior; furthermore, ethanol poses an increased risk of neuropsychological dysfunctions and poor academic performance ${ }^{4}$.

In order to restore or, at least, soften this severe public health problem, ANVISA has proposed restrictions to the publicity of ethanol regarding its content and time for exhibition on media. It has been demonstrated that these constitute an efficient intervention: countries where the publicity of alcohol is partially prohibited present a $16 \%$ lower level of ethanol consumption and a $10 \%$ less frequent occurrence of fatal car accidents ${ }^{5}$. Moreover, in opposition to market arguments, publicity autoregulation has proved to be useless in the trimming of the abuses of ethylic products' communication.

Although these data are highly significant, the public debate on this question remains insufficient. It urges a more extensive discussion of such matter and the support of health care providers in favor of the restriction of the publicity of ethanol. More important than the financial health of the industry, what must be taken into account is the impressive impact of alcohol on public health. We must not shun our responsibility. 


\section{REFERENCES}

1. Conselho de Comunicação Social do Congresso Nacional. Estudo sobre o álcool nos meios de comunicação. $1^{a}$ Reunião Ordinária do C.C.S; Brasília; 06 de Março de 2006.

2. Snyder LB, Milici FF, Slater M, Sum H, Strizhakova Y. Effects of alcohol advertising exposure on drinking among youth. Arch Pediatr Adolesc Med. 2006;160:18-24.

3. Carlini EA. Dados preliminares do II levantamento domiciliar sobre o uso de drogas psicotrópicas no Brasil - 2005. Available from URL: http://www.unodc.org/pdf/brazil/II\%20Levantamento\% 20Domiciliar\%20Dr\%20Elisaldo\%20Carlini_alterado2.pdf
4. Pechansky F, Szobot CM, Scivoletto S. Uso de álcool entre adolescentes: conceitos, características epidemiológicas e fatores etiopatogênicos. Rev Bras Psiquiatr. 2004;26(Supl I):14-17.

5. Babor TF, Caetano R, Caswell S, Edwards G, Giesbrech N, Grahan K et al. Alcohol: no ordinary commodity: research and public policy. Oxford: Oxford University Press; 2003. 